\title{
Reflection on Research into the Value Orientation of Public
}

\author{
Management \\ Cui Maochong \\ School of Public Administration, Yunnan University of Finance and Economics \\ Kunming, China 650221
}

\begin{abstract}
The value orientation of public administration research is a fundamental problem in the study of public administration. This article includes four aspects: First, summarizing the status quo of value orientation of public administration research; Second, the analysis of the structure of the value orientation of Chinese public administration; Once again, to reflect on the lack of value orientation of Chinese public administration, including such theory research perspectives as economics, public administration and institutional change; Finally, the paper proposes the fundamental direction of the research into the value orientation of public management.
\end{abstract}

Keywords: Public Administration; Research of Value Orientation; Reflection; Development Direction

\section{Introduction}

Since 19th century when Augustus Comte founded the positivism theory, the value analysis of social science research has been suspicioned and criticized by the so-called scientific activists.The scientific method was replacing the study of value when science of public management was born. Behaviorism which was prevalent from 1950s to 1960s in the West led this tendency to "ideology": researchers must remain "value neutrality", only factual judgments and analysis, and the rejection of a value judgment and reasoning. Therefore, for a long time, in the grand narrative of the public administration, public management value is a public management philosophy problem which has been ignored or intentionally forgotten. Considering that no matter how accurate scientific administration it is, how complex and logic of mathematical analysis model it is, respecting to public management practices, such efforts only have implemental and methodological significance, which can not touch the core issue of the public administration.

In the course of development of thirty years of after reform and opening up, few people can think value of the pursuit of the public administration as purposeful understanding, this not only makes the value of the public administration to fall into the superficial alternating cycles contradiction, greatly limiting the research vision, but also caused questions into the scope of their disciplines because of the lack of theoretical height which study of public management should own.

\section{Problem proposed: Review of Related Researches}

Since the reform and opening up, in order to promote quality and efficiency of the healthy development of our social economy and public affairs management, the value orientation of public administration has been gradually concerned by public administration theorists,thus leads to academic contention. The argument is: What does the value system of the public administration include, how to locate the value orientation of public administration?

Public administration value belongs to the scope of public management philosophy, so its investigation can not be separated from the macro analysis of the background of the development of philosophy. From the development of the history of philosophy, the subject of philosophical was ontology, epistemology and methodology respectively, but now theory of value is highlighted to the center position. Although public management philosophy is thought as an applied philosophy, some scholars disagree to construct the mode in accordance with the general philosophy, we can not ignore the influence of specific discipline philosophy 
caused by protruding "theory of value". After overviewing many western usages of the "value" Fu Lan Kena, a famous scholar,notes : People should choose a clear and systematic program, so as to be consistent when using these terms. Marx pointed out: 'Value', a universal concept, is produced from the relationships about people's need" "People use and performance attributes of the physical needs of human relations." This reasoning has very important guiding significance for the study of the value of public administration.

Academics generally believe that, the traditional science of public management is based on the theoretical logic of politicsadministration and bureaucratic system, public management is seen as a value-free area and a pure engineering technology. However, after carefully reading the writings of the early representatives of the science of public management, such as Wilson, Goodnow et al, we can find that due to be parted from the historical background, academics has a lot of misconceptions about their views. Robert - A • Dahl pointed out in his famous essay "Science in the Public Management: three questions":" researchers of science of public management can not avoid the consideration for the purpose of problem. They should avoid negligence in the purpose of the issue, that is ,obscure explanation about the purpose of the doctrine's basic ingredients. If the purpose and the normative consideration can always get clear statements, public management science will achieve real progress. If, however, refusing to recognize that the public management research should be established on the basis of clearly articulated purpose, that is to make the officialese the science in the field of medium-and long-term ethical purpose exist." Dahl points out the necessity and urgency of public administration's value studies. Respect to the discipline of public administration, it is difficult to define the scope of interdisciplinary research without clear value of public administration; respect to public management practices, it is difficult to locate the role of government accurately and carry out administrative activities effectively without clear value of public administration.

Wilson, the founder of public administration, said: "the goal of administrative study is to understand: first of all, the government can make sure what should be done properly and successfully .Second, how can the government complete the work with the least possible cost." During hundred years of development in the western Administration, along with changes in social, political, economic background and cultural conditions, the value orientation of public management has evolved as well. "Based on a different understanding of the value of certain basic administrative, three historical stages of development (paradigm) of science of public management were forming: the traditional Science of Public Management, New Public Management and New Public Management."

\section{The Value Structure of Public Administration}

\subsection{Efficiency: Instrumental Value of Public Management}

As Rosenblum, a public administration scientist, summarized, in fact, from the 1910s to the 1940s, the worldwide scientific management movement, which is based on the theory of Frederick Taylor, supports and develop such this hypothesis: effective and efficient management can be simplified as a set of "scientific principles", to study scientific management is to find these principles to maximize the labor productivity. It is the desire and pursuit of value to efficiency that producing and developing the theory of scientific management.

"Efficiency" refers to the maximum output obtained from a given amount of inputs, i.e., with the minimum resource consumption has the same effect, or to maximize the effect of the same resource consumption, also is often said that "value maximization "or" in a way to maximize the value of the configuration and use of resources". Public administration, especially the traditional public management, speaks highly of the objectives of the "efficiency", but has been criticized in the latter part of the course of development, such as the new public management clearly states: "practical or traditional public management is trying to find the answers to any one of the following two questions: How to take advantage of available resources to provide more or better services (efficiency)? How can we be able to spend less money to maintain the quality of service (economic)? New public management proposes an new problem: Whether such this service is to promote social justice or not? "As for the criticism about the target-"efficiency" of traditional public management, it is necessary to mention another famous public administration scholar -Marshall Dimock, he said: "For government staff, to meet the common needs of the public is the ultimate test of their actions and evaluation.” Dimock questioned the acception of the efficiency criteria (in particular, use 
mechanical efficiency guidelines) without hesitation, he believed that the mechanical efficiency was a "cold calculating which lacks humanity, and the successful administration was one kind of management activity which was full of enthusiasm, vitality and humanity, public management" is not a lifeless tool, but a series of activities, including designing, planning, thinking, training and constructing, which aimed to promote the social development.

\subsection{Fairness, Justice: The Fundamental Value of Public Administration}

Fairness is a topic occupying one's mind through the ages in the history of human development, many saints sages have done brilliant interpretations of fair problems from different angles. Since mankind has entered into the class society, a number of historical events all reflect that people want to overthrow the ruling class, to achieve the good wish of social fairness, thus makes it clear that the human unremitting efforts to achieve this goodwill.

Form the perspective of public management, fairness is seen as an instrumental value pursuit with the aim of ,to a greater extent, mobilizing the whole society's enthusiasm, initiative and creativity, so as to achieve the ultimate goal of perfection of humanity and sustainable development of society. Equal opportunity is in essence a kind of fair competition. The competition is a source of power on which the human civilization and social development depend, Public Administration should deal with all the competition entities with non-discrimination principle,makes them have equal opportunities to possess and utilize social resources; fair result essentially refers to distributive justice.

The value of the public administration is a natural state which public management pursuing, it reflects people's hopes, ideals, and beliefs about the public management. Only grasp correctly its true meaning, can we improve public management theory research, thus jump out of a purely formal technical rationality to achieve inner harmony and unity of the theoretical system of public management.

\subsection{People-Oriented, Social Harmony, \\ Sustainable Development: The Purpose \\ Value of Public Administration}

It is believed by Marx that people is the most active factor in the productivity, in the production process, the material just changes in the form of value, labor is the real source of wealth. American economist Schultz takes people with capital, technology as the essential business capital. In his eyes, human, as an important factor of production, is also a kind of capital investments, which plays a decisive role in value-added of the production process and the development of the social productive forces.

The meaning of people-oriented is human development and value realization. Just as Marx once said' human is the highest value of the human.' Humanity, which is the eternal topic of management philosophy to explore, is shared by all people, different from the animal's attributes. The starting point and purpose of the public administration are reality. The value of public administration based on "internal scale" is based on the relationship quality, which is the public administration "ought".

Judging from the political ideals, our country's social system determines the public administration powers to serve the purpose of safeguarding the interests of the people in the "Three Represents", the so-called "right of the people, love the people, benefits for the people", all around expanded, therefore socialist China has the ability to overcome obstacles alienation of the value of public administration and continue to promote the coordinated development of socialist material civilization, political civilization and spiritual civilization. It's all clear to us with a better vision towards the realization of the value of public administration. The emergence of public administration is the rational needs of human society.

Social harmony is to maintain good social order and adhere to sustainable development. The order is an indispensable part of human society, the basis for the existence and development of human society. The existence of the order is a necessary condition of all human activities, we usually refer to "stability is the premise and foundation for development" is of great significance in terms of the order of, without a stable social order, liberty, equality, developmental requirements can hardly to be achieved.

Sustainable development has drawn more and more attention, it has become a world, any country can hardly resist trends, even this trend has become an important content of today's international cooperation and international support. "But in the field of public administration, the scholars of this problem are in lack of attention it deserves, far smaller than the other disciplines of philosophy, law, economics and sociology of this problem, which is a very abnormal phenomenon. 
Toward sustainable development issues relating to human living environment, the government has the advantage of public power, and should be plenty of opportunities. In fact, the strategy of sustainable development proposed exerts a comprehensive and profound impact on the formulation and implementation of the government's public management. The government charged with the sacred mission of leading the people to build better homes and creating a happy life, sustainable development as a model of development of a culture of harmonious coexistence of man and nature, and therefore become one of the pursuits of the ultimate value of the public administration.

Although the instrumental value and purpose of the demands of the public administration live in a different rank, they are mutually supportive, complementary coordination, and together constitute the value system of public administration. It is noted that the author of the construction of the value system of public managementdoes not mean to exclude and deny the existence of the other values of public administration (such as the rule of law, democracy, and freedom from corruption). The coexistence of diverse values and mutual balance are the significant symbol of modernization of public administration.

\section{Reflect on the Value Orientation of Public Administration}

The value of public administration should be such an organic system which is constituted by different level of values. In the system, the purpose of the public management value and instrumental value remain harmonious, thereby it further demonstrates the reasonableness of the public management, and effectively gets rid of suspicion that public management is a "platter" of other disciplines.

For a long time, the value orientation of public management's research was great influenced by the scientific management with Portugal etc. as a representative, which view the efficiency of public management as the ultimate goal and the only value standard. It is hard to avoid regarding the public management as pure transactional technology field, thus unable to further improve the public management in the height of the theory. Wilson known as the ancestor of public management once said: Administrative is above the pure technical details of that kind of monotonous content, its substantiation lie in the higher principle, it and the unfailing principles derived from political wisdom and the political progress's eternal truths are directly related.
In the context of the philosophical theory of value diversion nowadays, increasingly rich and complicated public management practice promote the academic's reflection to the value of public management. In fact, in public management value orientation research we have too much attention to public management's elaboration of "reality", but lack of public management's exploration of "ought to"; Too much attention to public management technology application's thinking and interpretation, but lack of public management philosophy level's criticism and innovation. Modern public management practice environment have earth-shaking changes compared with over years ago: The world's political and economic integration trend unstoppable, public management "overflow" effect obviously, it has already beyond the sovereign state range of narrow field of vision, the economic globalization makes countries economic ties more closely. One honors all, One damns all. Extinction, ecological environment deterioration is the enemy of human. Global public management requirements in some matter interaction on the question of human interest to take consistent action and steps, but the real world as "countries with" "divide and rule" with insuperable contradictions. Global concerted action's every step forward to human pay great cost. All these are calling to establish the national public management value consensus framework on account of the era of globalization.

Peruse the early public administration's compile regard Wilson, Goodnow etc as the representative personage, we can find the view put forward by academic had a lot of misunderstanding. The reason is that we often garble quote out of context. Wilson known as the ancestor of public management once said: Administrative is above the pure technical details of that kind of monotonous content ,its substantiation lie in the higher principle, it and the unfailing principles derived from political wisdom and the political progress's eternal truths are directly related. We have too much attention to public management's elaboration of "reality", but lack of public management's exploration of "ought to"; Too much attention to public management technology application's thinking and interpretation, but lack of public management philosophy level's criticism and innovation.

Public management value evaluation is an important theory field of the Public management theory of value. Many abuses and corruption of public management operation is connected with not existing a scientific and 
reasonable public management value evaluation mechanism. In today's society, advocates of the concept of scientific development, the correct achievements view appeal, the desire of green GDP all reflect the public management's important value evaluation. Science of public administration value evaluation must stick to both the scale of the public administration value subject need and the scale of public administration value object properties. On the basis of the practice in public administration adhere to the unity of purpose and regularity. Only in this way, it can achieve the value evaluation of public administration reached a consensus on the issue, unified thought, thus solidarity, maintain social stability. At the same time it can avoid the authoritarian state in thought theory, form social environment of fully reflecting national conditions, incarnating public opinion, concentrated intelligence, mobilize all aspects of the positive factors and promote social development.

\section{The Current Situation of the Value Orientation of Public Management}

At present, our country is in the comprehensive transformation period, namely transformation form a single value society to multiple value the overall social. The development opportunity along with the transformation, all kinds of social contradictions, reflected in the public management practice and theory study, form a public management value conflicts, and the government's public management value conflict coordination directly influence public policy intervention of the economic development of the whole society.

Transition appearance of a large number of social injustice phenomenon become the hidden trouble which harm social stability and nice development. According to the theory of development economics, in the reform our country is in incremental reform stage. The purpose is to establish a market economic system. The reform of the system benefit to the whole social. The value orientation of "priority to efficiency and due consideration to fairness" is contribute to the establishment of our country market economy system. Into this century, however, significant changes have taken place in the situation of our country. The market economic system has been preliminarily established and need to be improved. The reform is in interest distribution stage. All kinds of social contradictions is increasingly prominent. Income gap, Regional gap, urban-rural gap is widening. It urgent need public management to adjust the specific gravity of the value orientation's structure, namely transferring fairness on the basis of efficiency for efficiency view on the basis of equitable. Let gradually mature market mechanism shoulder the responsibility of promoting social wealth growth. The government is for market economy system can't take into consideration, such as environmental damage, the income gap, inequality competition, etc., to carry out fair value shall be adjusted, so as to realize the people-oriented management mode and the development of harmonious society.

But, we can't ignore the value of public management coordination, because of the necessity conflict of the public management. Tendency of this kind of mistake is focusing too much on economic development, while ignoring the political democratization process. According to the new public management, public administration value is the goal of "efficiency" and "economic" add the goal of "social justice". We can solve the problem of public administrative value. However, the problem is not so simple. As well as there is a conflict between people for economic development and environmental protection, there is a contradiction between public management for the pursuit of "efficiency" and the pursuit of "justice". Such the hart puts it: "obviously, Efficiency standards may conflict other standard we evaluated public organizational work, for instance, the justice principle and the participation principle." In that way, this kind of public management value conflict between grades and up? The author argues that public administration value conflict, rooted in the development of productive forces brought about by the people demand the diversity and complexity, the needs of diverse and complex inevitably reflected in the field of public administration, namely, with the development of the society, people put forward higher requirements for public management. As mentioned above, people's pursuit for the development of the economy, more reflects the material aspects of the demand, the demand often conflicts with people demand for justice. The transition period in China, this contradiction is particularly prominent. Demand, then, this kind of conflict, reflected in the field of public administration value, has formed the "efficiency" and "justice" value conflict, thus it can be seen, the value of public management conflict with a certain inevitability. 


\section{Conclusion}

Certain public management activities always pursuit and embodies the certain public management value pursuit. In a sense, public management value conversion marked the different public management paradigm. Public management value is a category of relation, including the needs of value subject and value object of the activity and behavior of value subject and value object of the activity and behavior need to satisfy the relationship. From the Angle of layered, systematic and holistic consideration, the value of public management system can be divided into two levels: instrumental value, it includes efficiency, fairness and order; Terminal values, which includes sustainable development and perfect human nature, social harmony, etc.

Traditional value orientation in public management centered on fairness and efficiency of sorting, but as a result of government bounded rationality and market economy under the conditions of various stakeholders seek to maximize their interests, make public management on the implementation of results does not guarantee completely realize the balance of efficiency and fairness, "can only reach a relatively satisfactory balance". Many take the majority of public administration value can be regarded as efficiency, fairness and justice, people-oriented and derivative or a synonym for social harmony, these four value orientation can be for us to present a more complete public administration value structure, namely in the process of the pursuit of social justice, public administration, continuously adjust the relationship of fairness and efficiency, but the scale of regulation are based within the stable order, namely the scope of social tolerance.

In the new era put forward in the historical process of building a harmonious society in our country, the coordination of public administration value inner conflict, effectively promote the economic development and social all-round development, is still is placed in front of us a historic task. As the demands of the public management of instrumental value and purposeful value although at different rates, but they are all supporting each other, complementary coordination, constitute the value system of public management. To be sure: the value of public management system of construction does not mean that the rejection and deny the existence of other public administration value (such as the rule of law, democracy and clean, etc.). Multiple value of coexistence and mutual balance is actually public administration to modernization important symbol. Is to construct such a value system of public management, to distinguish the value orientation of public management hierarchy, the intention is to sketch a public management mode and direction.

\section{References}

[1] Perry.Value and evaluation [M]. Beijing: Chinese university press, 1989.

[2] Peng Heping. For foreign public administrative theory. Beijing: press of the central committee of the communist party of China party school, 1997. 154, 1.

[3] Peng Heping. For foreign public administrative theory [C]. Beijing: central party school press, 1997.

[4] Jin Taijun. The historical evolution of the western public administrative value orientation [J]. Journal of jianghai, 2000, (6).

[5] David Rosenbloom, Robert S. Kravchuk: Public Administration: management, political and legal ways, 18-19.

[6] Peng Heping. Foreign public administration theory Featured [M]. Beijing: Central Party School Press, 1997. 